\title{
マンガン団塊の年輪構造に沿った元素分布と 環境変動に対する考察
}

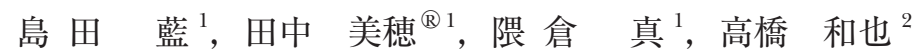

\section{Distribution of Elements along the Structure of Annual Rings of Manganese Nodules and Its Environmental Implications}

\author{
Ai Shimada ${ }^{1}$, Miho Tanaka ${ }^{1}$, Shin Kumakura ${ }^{1}$ and Kazuya Takahashi ${ }^{2}$ \\ ${ }^{1}$ Tokyo University of Marine Science and Technology, 4-5-7, Konan, Minato-ku, Tokyo $108-8477$ \\ ${ }^{2}$ RIKEN, 2 - 1, Hirosawa, Wako-shi, Saitama 351 - 0198
}

(Received 17 April 2005, Accepted 17 August 2005)

\begin{abstract}
Manganese nodules, which are mainly composed of manganese and iron oxide, show the structure of annual rings. Chemical compositions vary widely, such as the concentrations of Co, Ni and $\mathrm{Cu}$, and the relative ratio of $\mathrm{Mn} / \mathrm{Fe}$. It may be possible to analyze the old environmental changes from the chemical composition. In this study, characterization of the chemical composition of manganese nodules was performed to find the factors concerning the effect of a changing of environment. In the sample, a characteristic layer was found in a raster image of X-rays by SEM-EDX. In this layer, the abundances of iron and sulfur were high, but manganese was low. In this particular structure, pyrite should be considered to occur as very small particles. Further, manganese nodules were examined along the structure of annual rings in more detail for chemical composition, which confirmed the result of SEM-EDX. The main elements were analyzed by an inductively coupled plasma atomic emission spectrometer (ICP-AES), and trace elements were analyzed by an inductively coupled plasma mass spectrometer (ICP-MS). As a result, the distribution of the elements changed to $1 / 3$ from $1 / 2$ and $3 / 4$ from the center. The distribution of the elements changed one after another at the former. The latter agreed with the section at which there was sulfur when analyzed by SEM-EDX. The distribution of the elements suddenly changed at the same time at the latter. Therefore, we can guess that the different changes of the environment occurred twice.
\end{abstract}

Keywords : manganese nodule; structure of annual rings; element distribution; environmental changes.

1 はじめに

深海底に存在する鉄とマンガンを主成分とする酸化物で あるマンガン団塊は，微量金属元素を濃縮していることか ら海底鉱物資源の一つとして注目されている.鉱物資源と してだけでなく, 海洋環境中の微量元素の循環においても

\footnotetext{
*若手研究者の初論文特集

${ }^{1}$ 東京海洋大学海洋科学部海洋環境学科: 108-8477 東京都港区 港南 4-5-7

2 理化学研究所 : 351-0198 埼玉県和光市広沢 2-1
}

重要な役割を担っていると考えられている，そのため，マ ンガン団塊の組成特徵や生成機構などに関して多くの研究 が行われてきた12).

マンガン団塊は, 丸い形状を成し，その断面は，マンガ ン団塊の成長環境の変化によって化学組成の異なる年輪構 造を形成することが報告されている ${ }^{3)}$. マンガン団塊の成 長速度が数 $\mathrm{mm} / 10^{6}$ 年であること, マンガン団塊の平均 的な大きさが直径， $3 \sim 6 \mathrm{~cm}^{4)}$ であることから，その年輪 構造に沿った化学組成の検討は, 海洋の古環境を解析する 上で，重要であると考えられる。これまで，マンガン団塊 


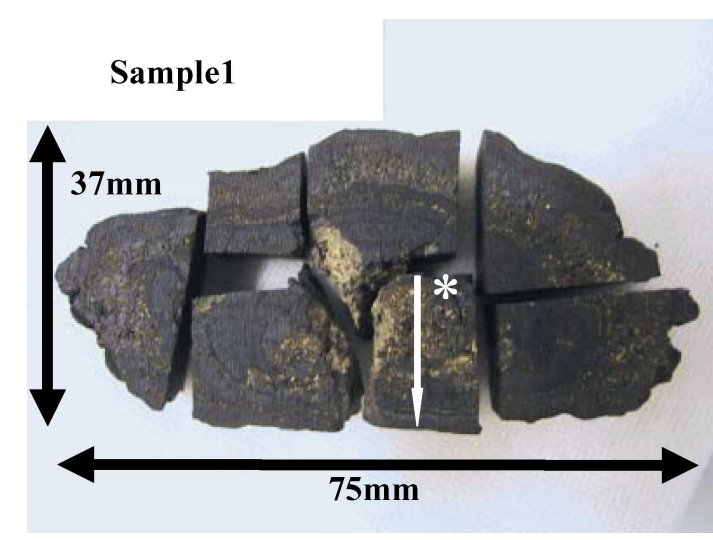

Fig. 1 Cross section of manganese nodule observed (Sample 1)

Manganese nodule was sliced with diamond cutter. Section $(*)$ was examined from center to edge by SEM-EDX.

の組成について多くの報告があるが，年輪構造に沿った組 成分布についての測定はされていなかった。 それは, マン ガン団塊の大きさにもよると考えられるが，本研究におい て, 年輪構造に沿って分割できる程度に大きい団塊を入手 できたので, 本研究では, マンガン団塊が成長した海洋の 古環境を調べる基礎データとして, 年輪構造に沿った化学 組成の把握と, 海洋環境の変動を反映する因子の抽出を目 的とした. 特に硫黄に対する重金属の相対存在度について 検討し, マンガン団塊の「履歴」について検討した. 後述 するように，本研究で対象とした試料はハワイ沖の鉱区か ら採取されているが, 鉱区との関連で詳細な産状（採取地 の地形や試料の存在状態など）は公開されていない.した がって, 特定地域の環境変動に関して, 踏み达んだ議論は 困難であるが，今回は，マンガン団塊から分析化学的に抽 出された情報の集積から推測可能な環境履歴を示し, 今後 の研究推進の基礎とした.

\section{2 実験}

\section{$2 \cdot 1$ 試 料}

試料は, (独)石油天然ガス・金属鉱物資源機構によって, 1996 年に第 2 白嶺丸にてハワイ南東沖マンガン団塊鉱区 西区（中心部位置： $10^{\circ} 10^{\prime} \mathrm{N}, 147^{\circ} 00^{\prime} \mathrm{W}$ 付近）で採取され, 譲渡されたマンガン団塊を使用した. 室温で保存してあっ たものの中から, 長さ $\times$ 幅 $\times$ 高さが, $75 \mathrm{~mm} \times 65 \mathrm{~mm} \times$ $37 \mathrm{~mm}$ と $82 \mathrm{~mm} \times 60 \mathrm{~mm} \times 50 \mathrm{~mm}$ の試料 1,2 を用いて 実験を行った。

試料 1 は，ダイヤモンドブレードを用いて先に示した 長さの方向におよそ $1.5 \mathrm{~mm}$ 幅にスライスし, 更に, $3 \mathrm{~cm}$ 角程度に切断した (Fig. 1). 測定面を炭素蒸着（JEOL 製 JEE-400 Vacuum Evaporator) し, 室温, デシケーター中

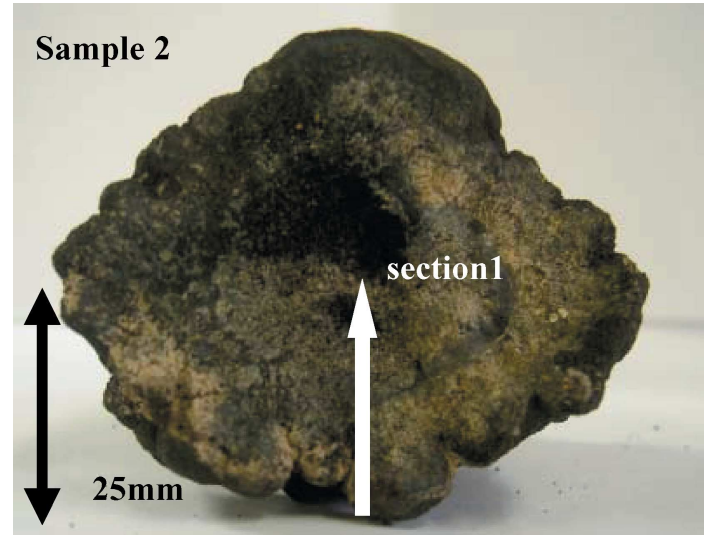

Fig. 2 Manganese nodule scraped (Sample 2)

Manganese nodule was divided crosswise and scraped from edge to center with microspatula.

で保存した。

試料 2 は, 先に示した高さの方向から十字に分割し, そのうちの一かけらについて，テフロンコーティングした ミクロスパーテルを用いて, 年輪構造ごとに 9 セクショ ンに削り分けた（Fig. 2)。削り分けた試料は，室温，デ シケーター中で保存した. 削り分けた試料 $0.5 \mathrm{~g}$ をテフロ ンビーカーに量り取り, 塩酸（関東化学製 Ultrapur）, フ ッ化水素酸（関東化学製 Ultrapur）をそれぞれ $3 \mathrm{ml}, 1.2$ $\mathrm{ml}$ 加え, ホットプレートで $200^{\circ} \mathrm{C}$ に加熱しながら溶解し, 室温に冷やし，1\% 硝酸溶液で $50 \mathrm{ml}$ に定容した．硝酸は， 関東化学製 Ultrapurを用いた。これを原液とした。 $1 \%$ 硝酸溶液として原液の 100 倍希釈溶液と 10000 倍希釈溶 液を調製した.

また，パイライトの標準としてはペルー産の標準試料を 用いた。

\section{$2 \cdot 2$ 分析方法}

固体試料の分析は, 中心を含む一かけらを選択し (Fig. 1), 走査型電子顕微鏡-エネルギー分散型 X 線分析 装置（SEM-EDX，JEOL 製 JSM6330F）を用いて，マンガ ン団塊の中心から外側へ向け, 半定量と元素のマッピング を行った、マンガン団塊の状態をなるべく恋化させないた めに，熱をかけず，SEMの真空に耐えられるように常温 で徐々に乾燥をさせ，測定を行った。まず，走査範囲を $2.4 \mathrm{~mm} \times 1.8 \mathrm{~mm}$ に設定し, 中心から外側へ 12 のセクシ ヨンに分け，測定した。更に，鉄と硫黄の濃縮に注目した セクション 10 について, これは, 中心からおよそ $3 / 4$ 程 度の位置にあたるが， $200 \mu \mathrm{m} \times 150 \mu \mathrm{m}$ の範囲でマッピン グを行った. 更に, $20 \mu \mathrm{m} \times 25 \mu \mathrm{m}$ の範囲内で点分析を行 い, 硫黄と鉄の原子数比について検討した（Fig. 3 及び Table 1). 

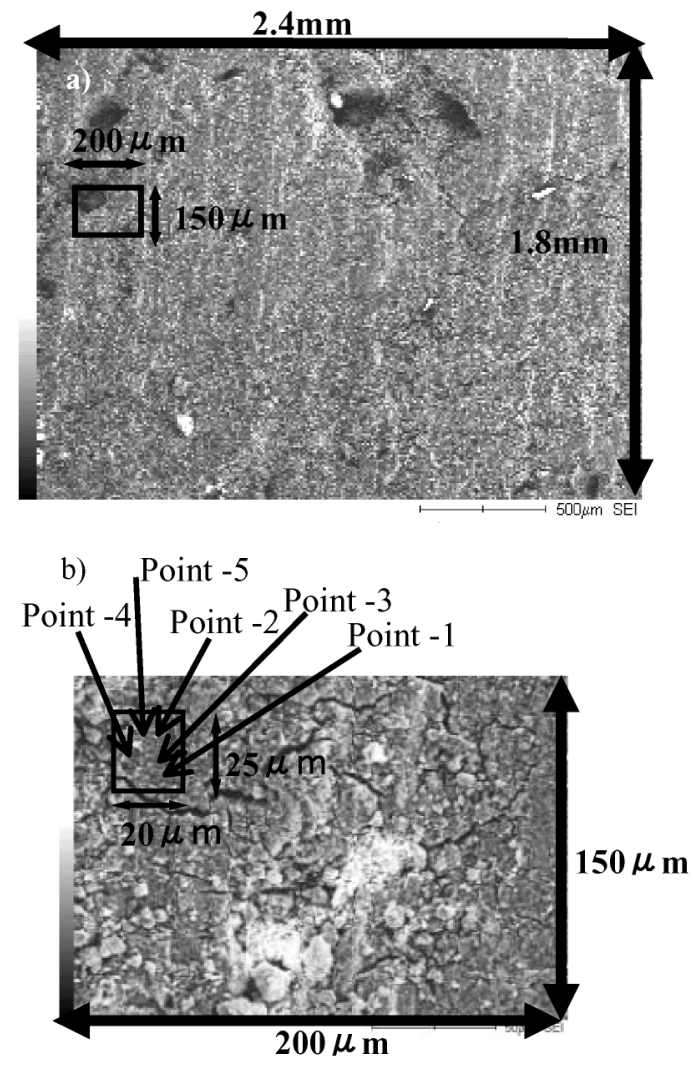

Fig. 3 Map of section 10, which is between 11 and 14 $\mathrm{mm}$ from the center

a) Enlarged map $(1.8 \mathrm{~mm} \times 2.4 \mathrm{~mm})$ of section 10 shows clear line of sulfur and iron but no line indicates of manganese on the same line. b) Enlarged map $(150 \mu \mathrm{m} \times 200 \mu \mathrm{m})$ of part of Fig. 3-a). Some points (points 1 to 5) are measured in the squares of $20 \mu \mathrm{m} \times$ $25 \mu \mathrm{m}$.

SEM-EDX での測定は，部分的な測定であったため，マ ンガン団塊の全体的な化学組成を把握するためにマンガン 団塊を溶解した実験を試みた。帯状に硫黄と鉄の濃縮が確 認されたことから，年輪構造に沿った化学組成の把握が重 要であると考え, 年輪構造に沿った測定を試みた.

溶液試料の分析は, 主元素 $(\mathrm{Mn}, \mathrm{Fe}, \mathrm{Al})$ については 誘導結合プラズマ発光分光分析装置（ICP-AES, HITACHI P-5200）を用い, 微量元素（Ni， Cu, Cr, Mo, $\mathrm{Zn}, \mathrm{Pb}, \mathrm{Se}, \mathrm{As}, \mathrm{Cd}, \mathrm{Sb}, \mathrm{U})$ については誘導結合プラ ズマ質量分析装置（ICP-MS，Thermo Electron PQ $\Omega$ ）を 用いて測定した。測定溶液は, それぞれ，原液の 100 倍 希釈溶液，10000 倍希釈溶液を用いた。検量線はSpex 製 の標準溶液 XSTC-469 を使用した。始めは内標準は In, $\mathrm{Bi}$ 各 $10 \mathrm{ppb}$ になるように添加したが，試料にも In, Bi が含まれており, 結果として内標準として機能していなか った。したがって濃度計算には, 単純に検量線法を用いた。 分析結果の妥当性については, 著者らのグループはほぼ同 時期に標準堆積物（MESS-3）に対する分析を行っており,
Table 1 a) Relative atomic number $(\%)$ in points 1 to 5 and the relative atomic ratio of sulfur to iron in the manganese nodule

\begin{tabular}{cccrccc}
\hline Point & $\mathrm{O}$ & $\mathrm{Si}$ & \multicolumn{1}{c}{$\mathrm{Mn}$} & $\mathrm{Fe}$ & $\mathrm{S}$ & $\mathrm{S} / \mathrm{Fe}$ \\
\hline 1 & 62.16 & 2.07 & 9.84 & 1.84 & 3.41 & 1.85 \\
2 & 60.72 & 1.88 & 13.93 & 1.32 & 4.99 & 3.78 \\
3 & 50.55 & 3.33 & 17.04 & 5.23 & 8.83 & 1.69 \\
4 & 50.06 & 1.92 & 15.09 & 4.78 & 5.31 & 1.11 \\
5 & 58.68 & 1.98 & 13.81 & 2.65 & 7.01 & 2.65 \\
\hline
\end{tabular}

b) Relative atomic number (\%) and the relative atomic ratio of sulfur to iron in two points of the pyrite standard sample

\begin{tabular}{clll}
\hline Point & \multicolumn{1}{c}{$\mathrm{S}$} & \multicolumn{1}{c}{$\mathrm{Fe}$} & $\mathrm{S} / \mathrm{Fe}$ \\
\hline 1 & 65.6 & 34.4 & 1.91 \\
2 & 64.34 & 35.66 & 1.8 \\
\hline
\end{tabular}

その結果は，既に報告済みである ${ }^{5)}$.

\section{3 結果と考察}

\section{3・1 SEM-EDX による観察（試料 1）}

Fig. 1, 2 から分かるようにマンガン団塊の切断面から, おおまかに黒い部分と白い部分からなる年輪構造を目視で 確認することができた. 半定量, 元素マッピングの結果, Fig. 4 で示すように, Si と Mn は逆の挙動を示し, マンガ ン団塊の中心部には主にシリカが存在し, 外縁部ではマン ガンが多く存在していた。 また，Fig. 5 に示すように，中 心から $3 / 4$ 程度のところに, 硫黄が年輪構造に沿って帯 状に濃縮していた。同じ部分で，鉄も同様に濃縮が見ら れ，マンガンは分布が低い層が確認できた. 更に, Fig. 4 から分かるように, 中心から $12 \mathrm{~mm}(3 / 4$ 程の部分) の 部分で, 多くの元素の相対質量 $(\%)$ の分布に変化が見ら れる．硫黄の濃縮と同じように正のピークが見られる元素 としては, Mn, Ni，が挙げられる。 $\mathrm{Si}, \mathrm{Al}, \mathrm{Fe}$ は, 減少 していた，顕著な変化として $\mathrm{Mn} / \mathrm{Fe}$ の值を示した（Fig. 6).このように，硫黄が带状に存在していた部分を含む 範囲において多くの元素の分布に変化が見られたことか ら, この時期に何らかの環境変化もしくは, マンガン団塊 の状態変化が起こったのでないかと考えられる.

また, 海水中では, 生物生産性が高い場所や熱水活動の ある場所では硫酸バリウムの結晶や微粒子が堆積物上に沈 澱する事が知られているが6)7), 硫黄のピークが見られた 分画において $\mathrm{Ba}$ のピークは確認されなかった。

Fig. 5-aに示されるように硫黄の濃縮された部分が狭い $(500 \mu \mathrm{m})$ 範囲であった. マンガン団塊の成因の一つに, 生物の関与（バイオミネラリゼーション）があると言われ ている ${ }^{8) 9}$. この硫黄層が, 硫酸還元菌などの生物活動に よるとすると, 海水の硫酸イオンからの生物活動で, 年輪 

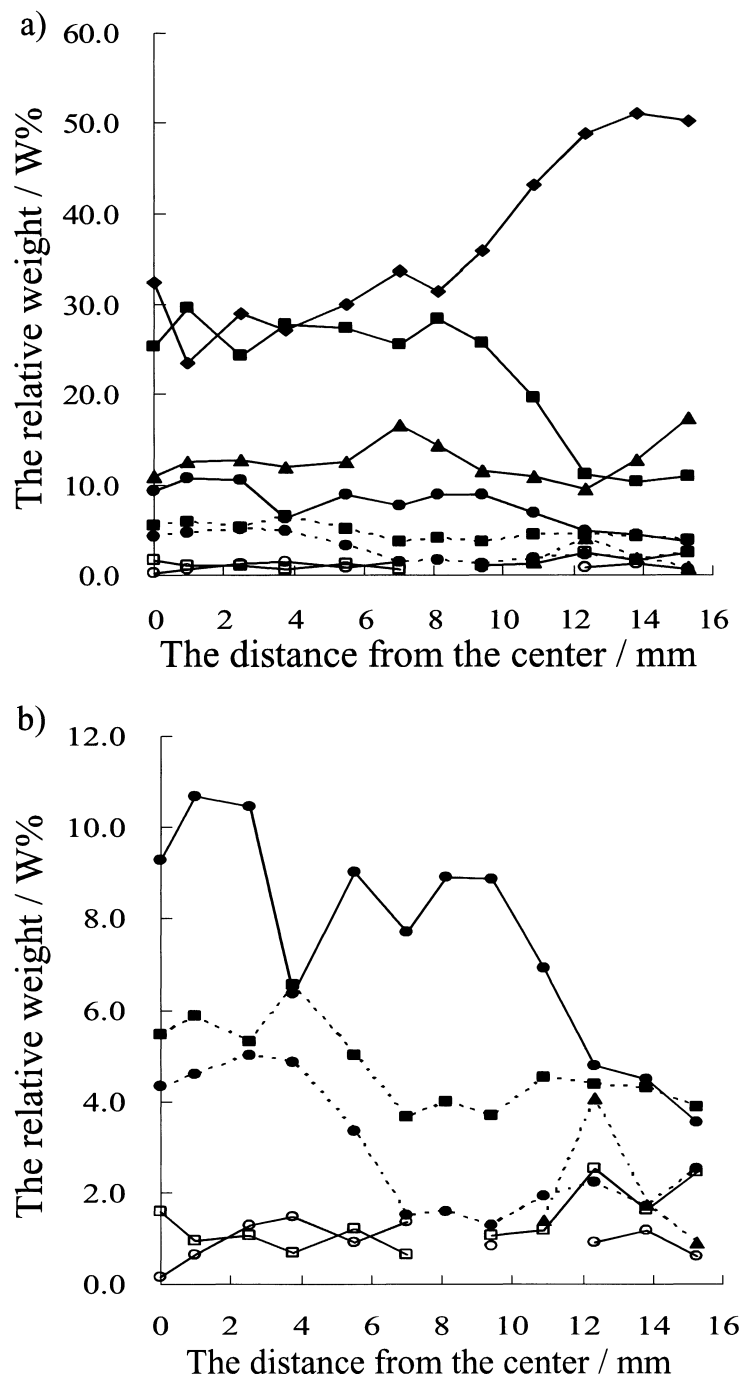

Fig. 4 Elemental distribution from center to edge of manganese nodule using a SEM-EDX

Sample was the manganese nodule shown in Fig. 1. a) Plots of relative weight $(\mathrm{W} \%)$ against distance $(\mathrm{mm})$ from center. $\mathrm{Mn} ; \boldsymbol{\mathrm { Si }} ; \boldsymbol{\triangle} \mathrm{Fe} ; \mathrm{Al}$; $\mathrm{Na} ; \mathrm{Cl} ; \boldsymbol{\Delta} \mathrm{S} ; \bigcirc \mathrm{Co} ; \square \mathrm{Ni}, \mathrm{b})$ Enlarged view of Fig. 2-a). $\mathrm{Al} ; \square \mathrm{Na} ; \mathrm{Cl} ; \boldsymbol{\Delta} \mathrm{S} ; \bigcirc \mathrm{Co} ; \square \mathrm{Ni}$

構造の一部に局在して硫黄が濃縮するとは考えにくいこ と, またこのマンガン団塊の産出した位置から考えて, 生 物的関与を否定はできないが, 海洋中の沈降物などから生 じたと考えた .

更に，硫黄と鉄の濃縮が確認できた帯状の部分について Fig. 3-bのように, より細かく硫黄と鉄の分布を測定し, 硫黄と鉄の原子数比について検討した（Table 1). 硫黄 が，20 $\mu \mathrm{m} \times 25 \mu \mathrm{m}$ の中で微粒子として確認された。硫黄 の生成はマンガン団塊の生成に伴って吸着・共沈したので はなく, 成長過程のある非常に短い時期に, マンガン団塊 中で生成されたのではないかと推測した。これに関して は, Table 1 に示すように, 非常に微細な部分で, 硫黄と
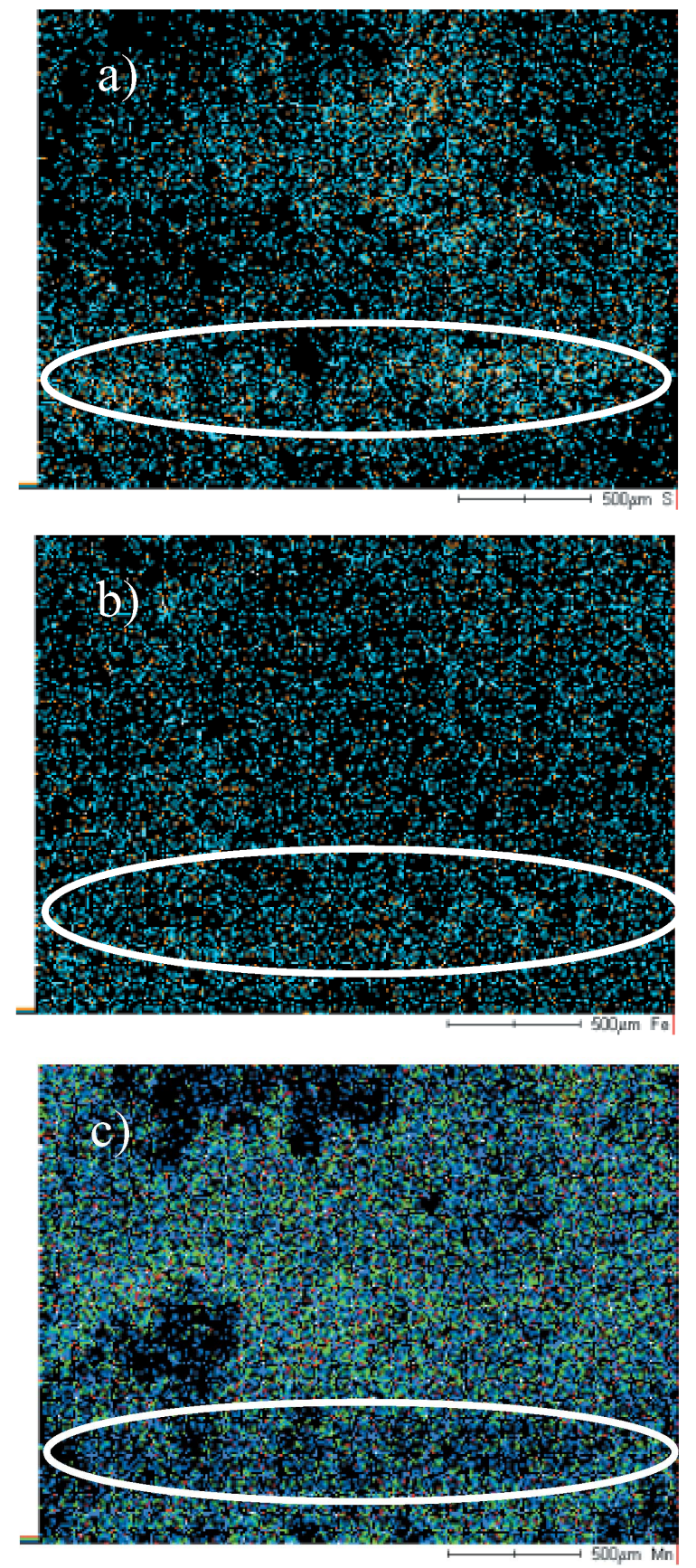

Fig. 5 Maps of sulfur, iron and manganese concentrations section 10 , which is between 11 and $14 \mathrm{~mm}$ from the center

a) sulfur; b) iron; c) manganese. A clear line was observed in the map of sulfur and iron concentrations but a dark line was observed in the map of manganese concentration. The distribution of sulfur corresponds to that of iron in the small width $(500 \mu \mathrm{m})$ of the line.

鉄の比が， 2 に近く，パイライトの標準試料と似た值を示 した、マンガン団塊の中に，硫酸イオンと鉄が結合した化 合物が生成していると鉄が 2 価では安定に存在しにくい ので，硫酸第二鉄 $\mathrm{Fe}_{2}\left(\mathrm{SO}_{4}\right)_{3}$ であろうと推定される.この 


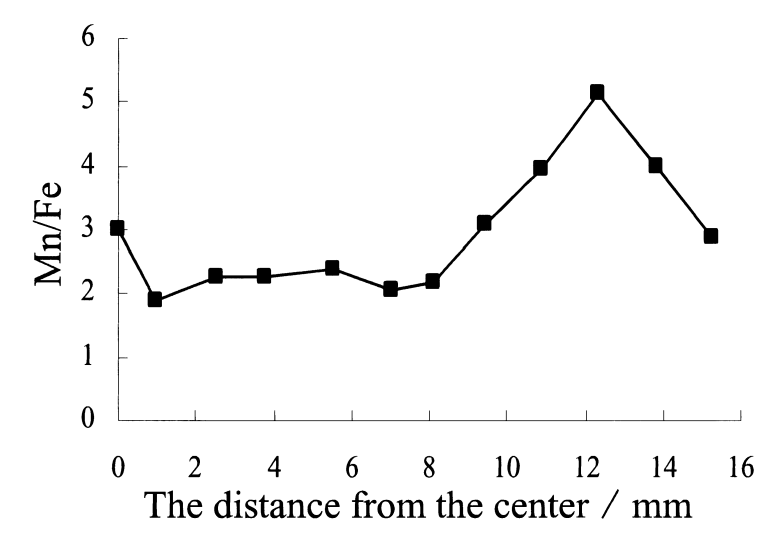

Fig. 6 Relative atomic ratio of manganese to iron against the distance from center

The relative atomic ratio of manganese to iron in section 10, which is between 11 and $14 \mathrm{~mm}$ from the center was markedly different from that of other sections.

場合には硫黄/鉄の比は 1.5 になる。パイライトの場合に は硫黄/鉄は 2 であり, この值だけではどちらの化合物が 生成したか, 明らかではない。この状況においては, 硫黄 がマンガンよりも鉄と選択的に結合する必要がある。そも そも海水の中には, 硫酸イオンが約 $2500 \mathrm{mg} / 1$ と塩化物 イオンの次に多く含まれているので, 多孔質であるマンガ ン団塊の特異な場所にのみ濃縮される理由が見あたらな い.これは溶液的に考えると, $\mathrm{Fe}^{3+}$ と $\mathrm{SO}_{4}{ }^{2-}$ の錯形成定数 が $4.04\left(25{ }^{\circ} \mathrm{C}, I=0\right)^{10)}$ と, $\mathrm{Mn}^{2+}$ と $\mathrm{SO}_{4}{ }^{2-}$ の錯形成定数 が $2.26\left(25^{\circ} \mathrm{C}, I=0\right)^{10)}$ であること, また, $\mathrm{Fe}^{2+}$ と $\mathrm{S}^{2-}$ の 錯形成定数が- $18.1 \quad\left(25{ }^{\circ} \mathrm{C}, I=0\right)^{11)}, \mathrm{Mn}^{2+}$ と $\mathrm{S}^{2-}$ の錯形 成定数がそれぞれ， -10.5 又は- $13.5\left(25^{\circ} \mathrm{C}, I=0\right)^{11)}$ と されており, 硫酸イオンよりも選択的に硫化物イオンが鉄 イオンと, そしてマンガンイオンょりも鉄イオンと反応し うることを示している. したがって, この硫黄の濃縮した 年輪構造の場合には, 硫化物イオン $\left(\mathrm{S}^{2-}\right)$ であり, この 硫黄が濃縮した年輪構造において, パイライトと考えると 妥当であろう。この硫黄の濃縮層は $500 \mu \mathrm{m}$ 程度と非常に 薄いものであった。この狭い層においても, 硫酸イオンで はなく, 硫化物イオンがあったと考えれば, より状況を説 明しやすい.この硫黄が年輪構造に沿って存在しているか に見えることからも, 硫黄化合物が一時期に生成されたこ とを支持していると考えた。この理由は, 硫黄の分布につ いて検討して行く上で $500 \mu \mathrm{m}$ と非常に狭い年輪構造にだ け, 硫黄が濃縮しているその生成過程を考えると, 海水の 中に硫黄が, 例えば $\mathrm{S}^{2-}$ のような化学形で, ある一時期だ け高濃度に存在し, マンガン団塊の表面だけで接触して形 成したと考えることが一番, 妥当ではないかと考えた。生 物，特にバクテリアによる硫黄の形成であれば， $500 \mu \mathrm{m}$ の範囲にだけ存在する理由はなく, より広領域に高濃度の
硫黄の存在が確認できても良いはずである。また，この $500 \mu \mathrm{m}$ において，マンガンの濃度が低く，鉄の濃度が高 いことから, 硫黄とはマンガンではなく鉄が共存している 理由があるはずである. 海水には硫酸イオンは塩化物イオ ンの次に高濃度で存在しているので, この高濃度領域にの み硫黄が濃縮される為には硫酸イオンが存在している, と いうことでは説明ができない.

このマンガン団塊がハワイ沖で採取されたことも考慮す ると，この硫黄の高濃度の年輪構造が生成した時期に海水 中に, 例えば火山性由来などで火山ガスが海水に溶解し, $\mathrm{S}^{2-}$ の濃度が急激に高くなった時期にマンガン団塊の表面 で硫黄と鉄が沈殿したと考えられる。

硫黄の分布に関しては, 海水中の硫酸イオンがあるため に, マンガン団塊を溶解させて, 硫黄を検出しても硫酸由 来か, $\mathrm{S}^{2-}$ 由来かは明らかにはならない。したがって, 硫 黄の高濃度に存在する年輪構造の周りでは, 硫黄がどの様 に存在しているのかを考えて行くためには，間接的ではあ るが， $\mathrm{S}^{2-}$ と結合しやすい重金属について測定し，その年 輪構造による変化を明らかにしていくしかないと考えた.

そこで，以下のような ICP-AES と ICS-MS により硫黄と 重金属の関係について考えた.

\section{$3 \cdot 2$ ICP-MS，ICP-AES による定量（試料 2）}

ICP-MS，ICP-AES による測定で得られた微量成分及び 主成分の濃度分布の結果を Fig. 7，8 に示す。検出限界以 下はプロットしていない。主成分の分布については, Fig. 7 で示すように, 中心から $7 \mathrm{~mm}$ 付近 $(1 / 3)$ で $\mathrm{Fe}$, $\mathrm{Al}$ それぞれ減少, 増加していた。また, 中心から $17 \mathrm{~mm}$ の付近 (3/4 程度の部分) で $\mathrm{Mn}$ と $\mathrm{Al}$ の増加, $\mathrm{Fe}$ の減少 が見られた. Fig. 8 から分かるように, 微量元素の分布に ついても，中心から 5〜13 mm（1/3 から 1/2）にかけて の部分と, 中心から $17 \mathrm{~mm}$ の付近 $(3 / 4)$ との 2 つの部 分で, 多くの元素濃度分布が変化していた. 前者について は, はじめに, $\mathrm{Pb}, \mathrm{U}, \mathrm{Cd}$ の減少と As の増加が起こり, 次いで, $\mathrm{Zn}$ の減少, $\mathrm{Sb}$ の増加が確認でき, 最後, 中心か ら 1/2 のセクションで Ni, Cr, Mo の増加のピークが確 認できた。後者については，同じ部分で， $\mathrm{Zn}, \mathrm{As}, \mathrm{Sb}$ の 増加, $\mathrm{Pb}, \mathrm{Cd}, \mathrm{U}$ の減少を確認することができた。

このように, これら二つの部分では, 濃度分布の変化の 仕方に違いが見られた．前者は，元素によって濃度分布が 徐々に変化しており, 時間差がみられた。後者は, 多くの 元素の濃度分布が急激に変化していた．また，Fig. 3 に示 したSEM-EDXによる測定から得られていた結果より，中 心から $4 \mathrm{~mm}$ (1/3 程度) 付近で $\mathrm{Al}$ が減少, $\mathrm{Na}$ が増加し, 次いで, $7 \mathrm{~mm}$ (1/2 程度) 付近で $\mathrm{Fe}, \mathrm{Mn}$ の増加, $\mathrm{Si}$ の 減少が見られた。既に示したように，中心から $11 \sim 14$ mm（3/4 程の部分）にかけての部分で, 硫黄の濃縮と 


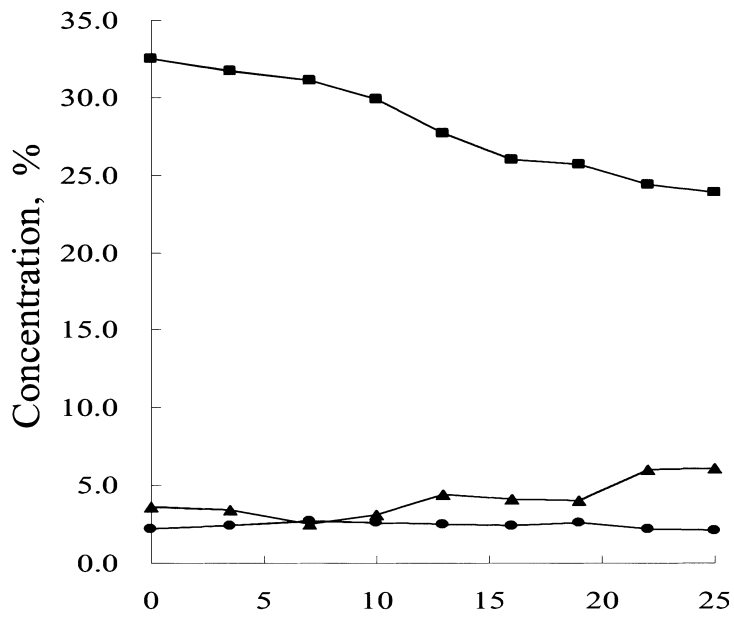

The distance from the center / $\mathrm{mm}$

Fig. 7 Elemental distribution from center to edge of manganese nodule by ICP-AES.

Sample was the manganese nodule shown in Fig. 2. Plots of concentration $(\%)$ against distance $(\mathrm{mm})$ from center. $\square \mathrm{Mn} ; \boldsymbol{\Delta e} ; \mathrm{Al}$



Fig. 8-a) Elemental distribution from center to edge of manganese nodule by ICP-MS

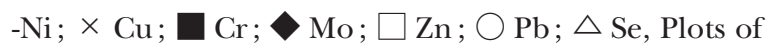
concentration $(\%)$ against the distance $(\mathrm{mm})$ from center.

$\mathrm{Mn}, \mathrm{Ni}$, の増加, $\mathrm{Si}, \mathrm{Al}, \mathrm{Fe}$ の減少が確認でき, 同じよ うな元素分布の変化のパターンを示し，異なるサンプルで の SEM-EDX の結果との再現性を確認することもできた.

$3 \cdot 3$ マンガン団塊の化学分析からの環境変動について の考察

こうした元素分布は，ホットスポットなどの火山活動に よる何らかの影響による成長環境の変化を反映したのでは

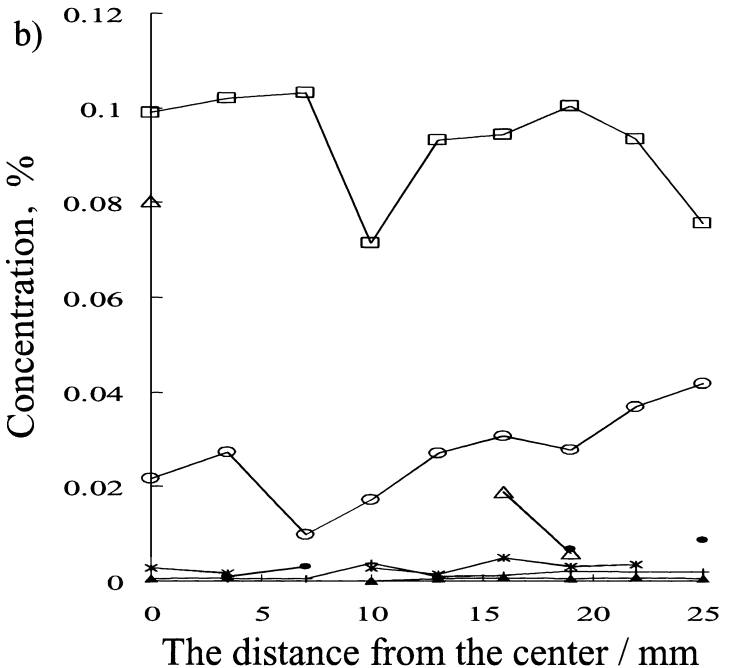

Fig. 8-b) Enlarged view of Fig. 8-a).

$\square \mathrm{Zn} ; \bigcirc \mathrm{Pb} ; \triangle \mathrm{Se} ; \mathrm{As} ; * \mathrm{Cd} ;+\mathrm{Sb} ; \boldsymbol{\Delta} \mathrm{U}$

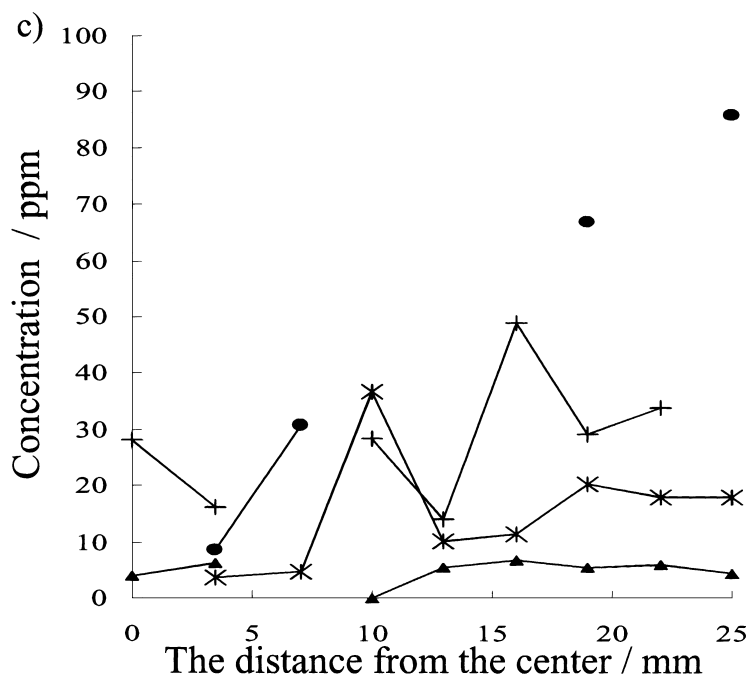

Fig. 8-c) Enlarged view of Fig. 8-b). Plots of concentration $(\mathrm{ppm})$ against distance $(\mathrm{mm})$ from center

As ; $* \mathrm{Cd} ;+\mathrm{Sb} ; \boldsymbol{\Delta} \mathrm{U}$

ないかと考えられる。

(1) 火山から流出した溶岩からの元素の供給

(2) 火山性のガスの溶解による急激な環境変化

以上の二つの影響を考えた。

前者は, 元素の濃度分布の変化に，幅があったことか ら，海底火山の爆発によって，流出した溶岩からの元素の 溶出とその元素のマンガン団塊への吸着が，元素の溶出の されやすさ，吸着のされやすさによって，徐々に進行した のではないかと考えた．岩石が溶融する際，溶融したマグ マに入りやすい元素と溶け残りの固体にとどまりやすい元 素に分かれやすいことも影響していると考えられる．固体 にとどまりやすいとされる $\mathrm{Ni}$ が最後に増加したことから 
も考えられる。

次に, 硫黄の濃縮が確認されたセクションで $\mathrm{Ni}, \mathrm{Mn}$, $\mathrm{Zn}$ など, 弱アルカリ性で $\mathrm{H}_{2} \mathrm{~S}$ を通じると沈殿するいわゆ る第 4 属の陽イオンが増加していた。逆に, 酸性下で $\mathrm{H}_{2} \mathrm{~S}$ により沈殿を生じる第 2 属銅亜族である $\mathrm{Pb}, \mathrm{Cd}$ は減少し ていた。しかし，同じ第 2 属の銅亜族である As や Sb は, 増加のピークを示した. Ni は一般に, As や Sb と S と化 合した鉱物が知られており，As，Sbが増加していたこと は, $\mathrm{H}_{2} \mathrm{~S}$ との反応における硫黄との親和性が強いことに加 えて, Ni との結合しやすいためではないかと考えられる. マンガン団塊の成長環境中に突如, $\mathrm{S}^{2-}$ が増加したことに よって, 海水中に溶存している微量元素と反応し, マンガ ン団塊表面に扔いて，このような硫黄と金属元素の濃縮が 起こった結果，急激な組成分布の変化を表したのではない かと考えた. $\mathrm{S}^{2-}$ の増加の理由として, 海底火山の爆発に よって放出された火山性のガスが考えられる。ガスの拡散 速度は，先に述べた，溶岩からの溶出に比べ速いために， 急激な環境变化が起こり, そのため, 一度に多くの元素の 濃度分布に急激な変化がみられたのではないかと考えてい る.

ここでホットスポットの例として, サンプル採取地点付 近で，現在も活動している八ワイの火山群を挙げると，八 ワイから西に続く火山列は打よそ 7000 万年前までさかの ぼれ，少なくとも 7000 万年間活動していることが分かっ ている ${ }^{1213)}$. 現在活動中のハワイ島のキラウェア火山を基 準にとると，北西端のカウアイ島は 560 万年前に，その 後, 100 万年間隔程度でハワイ諸島が形成されてきたとさ れている ${ }^{1214)}$. 使用した試料の大きさとマンガン団塊の成 長速度を $5 \mathrm{~mm} / 10^{6}$ 年と想定して ${ }^{4}$ 考えると，打よそ 500 万年から 800 万年前から生成されたものと推測した。中 心から $1 / 3 ， 3 / 4$ は，それぞれ，挍よそ 300 万年，100 万 年前程度に海水にさらされていた部分であると推測でき る.そして，300万年前にはオアフ島が，100万年前に, 八ワイ島が造られたとされている ${ }^{13) 144}$.これらのことから， 一つの可能性として, マンガン団塊の成長環境変化にホッ トスポットでの火山活動の影響が現れることは十分考えら れる. ハワイの火山群の活動との関係だけでも以上のよう なことが考えられる．八ワイの火山群とサンプル採取地点 とは約千 $\mathrm{km}$ の距離があり, 八ワイの火山群からの直接の 影響があったかどうかは確かではないが，過去，大規模な 活動や，サンプル採取地点付近に扔いて，同じような活動
があった可能性も考えられる，これらのことから，マンガ ン団塊の生成過程で, 2 回の大きな異なった環境変動が起 こったことが推測できる，今後は，沈殿過程における重金 属の化学形の変動と硫黄の化学種の変動に関して, 化学種 分析を加味しながら溶液化学的な研究をあわせて行うこと により，マンガン団塊の生成過程と環境因子との関連につ いて明らかにできると考えている.

マンガン団塊を譲与いただいた(独)石油天然ガス・金属鉱物資 源機構に厚く御礼申し述べます。

本研究の一部は, 東京水産大学教育研究推進費, (財) 鉄銅業環 境保全技術開発基金環境研究助成金，(財) 岩谷直治研究記念財団 科学技術研究助成金, (独) 日本学術振興会科学研究費補助金 樭 盤研究 $(C)$ 課題番号: 17550074$\}$ により, 行われた。また, 前東 京水産大学隆島史夫学長にも多大な援助をいただきましたので, 扮礼申し上げます。

$\left(\begin{array}{l}2004 \text { 年 } 3 \text { 月, 日本化学会第 } 85 \text { 年 } \\ \text { 会及び } 2004 \text { 年 } 9 \text { 月, 日本分析化 } \\ \text { 学会第 } 53 \text { 年会において一部発表 }\end{array}\right)$

\section{文献}

1) 竹松 伸: 海の研究, 4, 287 (1995).

2) 竹松 伸: 海の研究, 3, 277 (1994).

3) 竹松 伸: 海の研究, 5, 311 (1996).

4) 竹松 伸: “マンガン団塊一その生成機構と役割”, p. 1 (1998), (恒星社厚生閣).

5) 隈倉 真, 田中美穂, 橋本 晋, 前田 勝: 分析化 学 (Bunseki Kagaku), 53, 1101 (2004).

6) 環境保健クライテリア: 107 (Environmental Health Criteria 107) <http://www.nihs.go.jp/DCBI/ PUBLIST/ehchsg/ehctran/tran1/barium.html > .

7）前田玲奈：地質ニュース, 528, 10 (1998).

8) 佐藤義夫，小野信一，加藤義久，福江正治，中村 智已，竹松 伸: Bull. Soc. Sea Water Sci., Jpn., 59, 40 (2005).

9) 佐藤義夫，林 順子，西森真理，小野信一，竹松 伸: 海の研究, 4, 193 (2000).

10) R. M. Smith, A. E. Martell: "Critical Stability Constant Vol. 4”, 79 (1976) (Plenum Press New York and London).

11) R. M. Smith, A. E. Martell: "Critical Stability Constant Vol. 4", 76 (1976) (Plenum Press New York and London).

12）松久幸敬，三村弘二，須藤 茂，曾屋龍典：地質二 ユース, 6, 32 (1980).

13) < http://www.ehime-u.ac.jp/ grc/titei-1-6.html>

14）奈須紀幸: “海洋学講座 5 海洋地質学”, p. 198 (1976), (東京大学出版会). 
要旨

マンガンと鉄の酸化物であるマンガン団塊は，その成長環境における環境変化によって，化学組成が異な る年輪構造を形成することが知られている。八ワイ南東沖海底にて採取された試料について，その化学組成 の特徵を把握すること，環境を反映する因子を抽出することを目的として実験を行った．まず，走查型電子 顕微鏡一エネルギー分散型 X 線分析装置（SEM-EDX）を用いて年輪構造に沿った元素のマッピングを行っ た結果，年輪構造に沿って，パイライトが濃縮していると考えられる微小な層を見つけた．更に，より詳細 な化学組成を分析するため, また, SEM-EDX の結果の再現性を確認するため, 別の試料を年輪構造に沿つ て削り分け, 溶解し, 主元素, 微量元素についてそれぞれ誘導結合プラズマ発光分光分析装置（ICP-AES）, 誘導結合プラズマ質量分析装置（ICP-MS）を用いて定量分析を行った。切断し分析した面は，ほほ棈円形 となっているが, その短径の方向に中心から直径の $1 / 3$ から $1 / 2$ にかけての範囲で, 元素によって段階的 な分布の変化が見られた。また，SEM-EDX で硫黄が濃縮していた層と相対的に同じょうな位置（中心から 3/4）で多くの元素の分布に急激な変化が見られた．以上のことから，マンガン団塊の生成過程で，2回の 異なる環境変動があったと考えられる。試料採取地点がハワイ沖であることから，ホットスポットなどの火 山活動による何らかの影響を受けたと考えられる．元素によって段階的な分布の变化が見られた部分につい ては, 火山から流出した溶岩からの元素の溶出, 多くの元素について急激な分布の変化が見られた部分につ いては，火山性のガスによる影響が考えられる。 